\title{
The Journey to Medical Graduation in Ghana
}

Ghana Med J 2019; 53(4): 254-255 doi: http://dx.doi.org/10.4314/gmj.v53i4.1

November 2019 marked 50 years since the graduation of the first batch of medical doctors trained in Ghana. In this issue of the journal we re-publish in full the account of the journey to graduation as told by one of the doctors at the graduation event and as published in the Ghana Medical Journal. ${ }^{1}$

Mr. Chairman, Vice-Chancellor, Members of the University Council, Dean of the Medical School, Your Excellency's, Distinguished Guests, Ladies and Gentlemen: I have great honour in replying to the toast of the Dean on behalf of the first batch of medical doctors trained in Ghana. Today will stand supreme in the lives of most of the people here, particularly the young doctors. It will be remembered as the day on which they were given out to the world at large and accepted by them as graduates of the University of Ghana. What you are witnessing here tonight is the end of a journey once described as the "long and dangerous march to medical graduation in Ghana'. I intend to give you a brief account of what this long journey entailed. For the purposes of clarity, the journey must be divided into three phases - the Premedical era, the Preclinical era and the Clinical era.

\section{Pre-medical Course}

The first era started in October, 1962 when a batch of 51 young Ghanaians who had applied to do Medicine overseas were rounded up within a week and put in the University of Ghana with the understanding that the American government would soon sign an agreement with the government of Ghana for the establishment of a Medical School. This era lasted two years and we were expected to do in addition to the normal science subjects, others like Economics and English Language perhaps because it was felt that we needed the elements of economics to help us in choosing drugs for patients according to the cost of comparative drugs on the market. Towards the end of the second year, the arrangements between the government of Ghana and the American government broke down so that the students were left stranded with nothing concrete ahead for us after June 1964. Luckily for us the Ghana Government decided to go on with the project all alone and to make use of the manpower available, if the rest of the world would not come to her aid with teachers, technicians and equipment. This era stands unique because we were suddenly turned from docile and shy Ghanaians into neglected and rather ridiculed medicos who had to fight for everything that they thought they deserved. We had to fight endlessly to impress the authorities that subjects like Economics and English Language were not essential for the course. We also felt that the 'Premed' course was too long, if not entirely unnecessary.
We are happy to note now that the above subjects have been scrapped; the course shortened to one year and even some students are entering the preclinical stage none the losers for skipping the 'Premed' stage.

\section{Preclinical Years}

This phase started in October 1964 with a cocktail party giving a verisimilitude for another wise almost non-existent medical school. The school then consisted of 41 students, the Department of Anatomy manned by Mr. Quartey, F.R.C.S and Dr. Fred Engmann, and the Administration headed by Professor Easmon as the Dean and Dr. Otoo as Vice Dean. At the beginning of the second term the Physiology Department was started by Dr. Harold Phillips and that of Biochemistry by Dr. Andoh in the third term. This phase, like the Premedical era, was full of protests and sit-downs, this time over scholarship grants. At one point there was a baby-strike which lasted five working days. At a meeting between the entire student body and the Academic Board, with the Registrar of Scholarships as a guest, the authorities decided to bend us back by invoking the name and person of the ex-President of Ghana. Needless to say the students were not impressed and they persisted in their demand still the exPresident agreed that the scholarship grant should be increased from $£ 40$ to $£ 100$ a year, ahead of all other science students in Ghana. This unfortunately has been reduced again, causing much financial strain on the medical students.

\section{Clinical Phase}

This was by far the quietest era for there were fewer protests and few annoying situations. All the same the new Registrar of the School was given a rousing welcome within a few weeks of his assuming duty, in the form of a few hours sit-down which nearly sent the Dean's blood pressure and the Vice-Dean's heart rate to dangerous levels. We are sure the Dean needed a shot of Vegolysen and the Vice-Dean an emergency E.C.G. to bring the situation to the status quo ante. All too soon the seven-year journey came to an end in June 1969, But alas! The longawaited passing out of the first batch of Ghana-trained doctors came to the powers that be as an abortion (to quote an eminent Ghanaian Professor). 
We were handed over to the Ministry of Health which had claimed time and again that the Medical School could never have been if they had not provided us with lodgings for our Cadavera or the lab coats and dissection tools. They were so unprepared for our sudden emergence from our eggshells that they could not even engage our services immediately and had to force us to take onemonth leave-cum-holidays.

\section{Post-graduation}

After sitting at home for some weeks, individuals got fed up with the boredom and a few besieged the Ministry only to be told that postings were not out and nobody could say when we were supposed to start. One doctor was never written to, even though he sent his address on his application form and so he continued giving talks in Northern Ghana till late in August whilst his station had been informed that he was to take up his post on $1^{\text {st }} \mathrm{Au}-$ gust.

What has gone on in the recent press about the new doctors needs no repetitions here. Enough has been said and we expect more will be said soon if nothing is done urgently. The problems of accommodation, remuneration, boarding and transport are no new problems and surely, they can be solved easily if the goodwill to do so exists with those who are expected to solve them. We have been co-operative and will continue to be that way for all time. We must say here, however, that the rest of the world, especially the many Ghanaian doctors working abroad, will be watching what the Ghanaians do to their owntrained doctors and should they find that our own people have nothing much for us we stand to lose in our future post-graduate work overseas. Unless the conditions are also improved, we cannot see how these Ghanaian doctors will be cajoled into coming home. We should not be tempted now into thinking that we can dispense with the services of the Ghanaian doctors trained abroad because we shall be producing our own doctors locally who can do equally well, if not better. There are two main reasons for the above caution:

1. Local standards will definitely fall if the students under training here become aware of the fact that in Ghana remuneration for services seems to depend more on one's "contacts" than on one's performance. These "contacts" are ready to speak in high places for some doctors of similar status to have higher salaries than their counterparts when there is no reason performance-wise to justify such a move.
Once these students are convinced that there is discrimination against them they will relax, and when this happens we have really had it then and for a long time.

2. About half the number of doctors practicing in Ghana presently are not of Ghanaian extraction. These doctors will sooner or later leave as the living conditions keep rising. Should the exodus be massive in one year we may find ourselves in great trouble with Ghanaian doctors refusing to come home and those locally trained so belittled as to be unwilling to give of their best. Where shall we be then?

\section{Conclusion}

Mr. Chairman, we should not let this day pass without thanking all those who started us off and guided us through this catalogue of trouble to where we are now. A lot of people have helped us, and we would like to mention a few names: Dr. Cornor Cruise O'Brien, Professor Ewer, Mr. Quartey, Dr. Engmann, Dr. Phillips, Dr. Andoh, Dean Easmon, Dr. Otoo who fought hard to get the school going and all the other members of staff who rallied round the flag and kept it flying. We would also like to thank the Editor of the Ghana Medical Journal for the sympathy and assistance he has given us during our recent fight for basic rights (Ghana Med. J., 1969). Finally, Mr. Chairman, I would like to add my own congratulations to the many already offered to my colleagues who had the resolution, courage and stamina to weather all the storms which kept on blowing all around us. We only hope that the authorities will cashing on the experiences we have been through hand use them as guidelines for future action so that our younger brothers and sisters still in school be spared the frustrating and bitter experiences which have been our lot and still continue to be so. Before I take my seat | shall take this golden opportunity to express now and always our sincere thanks to the Ghanaian taxpayer without whose worthy contribution our education could never have taken place.

Thank you.

Dr J. O. O. Commey MB, ChB

\section{Editorial Office, Ghana Medical Journal}

\section{REFERENCE}

The journey to medical graduation in Ghana. Ghana Med $J$ 1969;8(4):297-8 